\title{
The Economic Policy of Japanese Naval Government in South Sulawesi in the Second World War 1942 -1945
}

\author{
Rasyid Asba \\ Faculty of Humanities, Hassanudin University, Makassar \\ *Corresponding Author: rasbawecu@yahoo.com
}

Received:

14 April 2017

Accepted:

18 December 2017

\section{Abstract}

The Japanese economic policy in South Sulawesi seemed to have different policies when compared to the other colonies in Indonesia. It was indicated by leadership typology of Japanese Navy which based in Makassar, Bukittinggi, and Java. In South Sulawesi, the policy was more focused on the compliance of logistic materials by strengthening on clothing industry, plantation of cotton and castor oil, and fisheries. The important policy of the army was the agricultural massive production sector to support the war. In addition, the agricultural and industrial sectors were also developed such as salt, castor oil, textile, silk, handicrafts and the like. Those phenomena analyzed by historical method. It used archives such as Japanese occupation reports in Makassar, Romusha archives in Makassar, and Japanese local politic documents in South Sulawesi. The reports on Japanese economic activities in South Sulawesi were also consulted. Information from magazines and newspapers were also taken such as Pemberitaan Makassar, Bintang Timoer, Sinar Baroe, Soeara Asia, Hong Po, and Pemandangan. In addition to, it has complied oral history with direct interviews to the people who are still alive and experienced on the era. The Japanese economic policies in South Sulawesi influenced great changes in new economic structure on the emergence of the diversification of popular-based commodity especially clothing and foodstuff during the war. That was the reason why people in South Sulawesi directed to execute intensification of agriculture in a professional productive manner supported by communal industrial policy.

Keywords: Economic Policies; Japanese Naval; South Sulawesi.

\section{Introduction}

The effect of war and the Japanese occupation led to comprehensive changes in economic structure in South Sulawesi. The main objective of Japanese invasion in South Sulawesi as it was to other parts of Indonesia was to explore its economic resources. With its fertile land and big population, South Sulawesi was considered as an extraordinary potential economic resources area. In such case, the Japanese took 
advantage of the population as logistic resources (Murtono 1968). The Netherlands Indies was governed under the Japanese doctrin Commonwealth Environment of the Great East Asia which involved the whole Southeast and East Asia. The Japanese economic activities were led to logistic aspects where Japan became its headquarter. The people of South Sulawesi were insisted to support not only the Japanese military occupation but the military operations in a wide scale as well. The foodstuffs production became a priority to supply the military for the Great East Asia war. Although South Sulawesi had been able to be self-sufficient in foodstuff at the Netherlands Indies era, this condition was unable to sustain under Japanese occupation because there were so many productions to be encouraged as the impact of war (Paeni 1985).

During the war, the commodities exchange was restricted to only the areas under Japanese control and this led to a great change in the ratio of supply and demand. In addition to foodstuff production, textile production was also given a priority because, in the Dutch era, Java depended most of textile supply on import. It was the reason why the Japanese military instructed the farmers to plant cotton, mulberry, rosella, and jute. Many agricultural plants such as tea, coffee, and sugarcanes were replaced with core plants since there was no more marketing value and at the same time, they had overproduction. This condition made the farmers had no option to plant any commodity on their land. The government strictly restricted the land to cultivate and it reminded us the forced plantation system in the century (Sutter 1959).

At the end of twentieth century the Dutch government by Pax Nederlandica developed economic integration by creating the center of economic growth in every region. In East Indonesia region, it was based in Makassar while South Sulawesi became foodstuff barn of Netherlands Indies which was supported by policies that encouraged the economic growth at the outside of Java (Kurasawa 1993). Many irrigation facilities were developed in South Sulawesi such irrigations in Bila, Bengo, Leworang, Palakka, Tempe, Sidenreng, Tallo, and Jeneponto. These irrigations had increased irrigated rice fields from 20,500 acres to 57,000 acres in the early 1936 and at the end of 1936 to 227, 193 acres. Such increment gave impact on the increase of rice export rate from $\mathrm{f}$. 300,000 to $\mathrm{f}, 300,000$. During the Japanese occupation, the rice production decreased because of many irrigation facilities were malfunctioned and caused the rice export rate lower down to f 2. 7000.000 in 1943 (Indische Verslag, 1943: 344).

\section{Method}

This is a historical research using archives sources either in manuscript forms or interviews particularly in associated with economic policies in agricultural sectors (namely: cotton plantation, the salt industry, and fishery) and their implementation in the areas occupied by Japanese naval government. This research used interdisciplinary approach such as historical and economical approaches based on 
documentary archives sources and interviews on community figures which played roles in the era of Japanese occupation in South Sulawesi.

The primary data were taken from the collection of The Library and Archives of South Sulawesi in Makassar. The data included documents on Sulawesi Province, documents on East Indonesia State, reports on Japanese occupation activities in Makassar, Romusa activities in Makassar, local politics during the Japanese occupation in South Sulawesi, brief notes on trading activities in East Indonesia State.

The data were also taken from the Indonesian Nasional Archives in Jakarta included Gouvernement Secretarie, Inventaris van het Archief van de Algemene Secretarie en Het Kabinet van de Gouverneur General 1944-1950. These two documents contain Besluit (stipulation) about trade policy in Makassar and also economic and political conditions. In addition to such documents, the writer also used oral history to make deeper analyze on the problems (Portelli 1991). It is recorded interviews cassette by M. Saleh Lahade, Riri Amin Daud, Kawilarang, and others.

Data in published archives materials at Koninklijk Instituut voor Taal-Land-en Volkenkunde (KITLV) in Leiden, Koninklijk Instituut voor De Tropen (KIT) in Amsterdam and at Indonesian National Library in Jakarta were also consulted. Data in books, journals, and newspapers about Makassar as a trading city were also included. Enomische Berichten Oost Indonesia 1949; The Economic Review of Indonesia Vol. 1 1947, Vol. 6 1952. Center for Statistical Bureau entitle, data on export-imports in several major ports during 1947-1958 all were consulted. The magazine entitled Berita Ekonomi 1951-1956, Mingguan Tempo Doeloe which contained information on South Sulawesi economy after independence.

\section{Economic and Financial Policy}

In a short time, Japanese military controlled most of Southeast Asia region and other East Asia. There was a notorious slogan of Japanese military" The God wind makes all the dry leaves fly. Sinar Baroe with this slogan the Japanese military occupied the area instantly (Sinar Baroe, 25 Juli 2065). With unpredictable powerful military troops, they invaded every state they passed through without any resistance. The Japanese military reached Indonesia lastly where Manado was the first to be occupied followed by other regions such as Kalimantan, Sulawesi, Sumatera, Java, and Jakarta.

No one could argue that the expansion of Japanese occupation to Asia and Pacific regions needed a great expenditure on materials, natural and human resources and because of this situation, and for fundraising, the Japanese military established some efforts in economic sectors to finance the expensive war. The Romusha (forced labor) system was implemented in the whole hinterland areas.

Such mobilization of the people was not only conducted by the military itself with the slogan colonialization release of Great Asia, but it was also done national movement figures who directly encouraged the people to support the war done by Japanese Military (Dai Nippon) (Soeara Asia, 18 Mei 2064).

Another way to enhance the economic activities to finance the war was to do promote economic policy that emphasized the maximum exploration of natural 
resources. With this exploration of natural resources gave impact on massive agricultural products in most of the areas controlled by the Japanese military. Such products were rice, second crops, corn, etc. The important policy of Japanese military was massive production on commodities that supported the war such as cotton, rubber, and castor-oil plant project for alternative energy, especially for the airplane.

The Japanese made propaganda not only in political aspect to make Great Asia free from colonialization but also an economic aspect as well. At the wartime which was more and more became dreadful, the war that also involved Indonesia, the economic sector became very crucial to back up the military in order to win the war.

The progress of education in South Sulawesi under Japanese naval government let to the establishment of schools and an increasing amount of pupils. For example, there were 3791 people elementary schools with 2.375 .600 pupils (Sinar Baroe, Djoeni 2604). In addition, there was coffee and tea plantation movement together the intensification of foodstuff materials such as rice, corn, and tuber. This program was under the supervision of Juyoshokuryo Kanri Jimusho (The Main Foodstuff Supervision Office) who was also given the charge for marketing, storage and setting up the price. Obviously, the economic condition at the wartime was bad in relation to the price rises in the trade sector. The price of daily needs of the people increased significantly high (especially for cigarette raised to two folds). The price of toothbrush raised from 30 cents to $50-85$ cents, white thread from 1,5 cents to 4-71,5 cents, white shirt from 125 cents to $250-275$ cents, 1 -yard white cloth from 14 cents to 40-45 cents (Soeara Asia, Januari 2064).

To dominate Netherlands Indies economy, the Japanese prime minister designed the economic development program for the common wealth. He said that the majority of people in Great East Asia would become a priority in the development of forestation, agriculture, and fishery to equalize the industrial sector. Some efforts had been done to distribute the foodstuff based on people needs.

At the meeting of People Representatives of Tokyo at 28-01-2603 (1943) Okinori Kaya, a Japanese Ministry of Finance delivered his speech on fiscal policy to the council. According to him the Japanese economy is good and the finance is sufficient. The southern area would be developed and the economic relationships among the Japanese ally was also satisfactory. In order to win the Pacific war, the economy had to be strengthened. The Japanese economic policy was merely directed to win all aspects and to avoid the distortion of government activities to satisfy this condition, some aids for economic empowerment were given as the following; a) improving people health 78 million yen; b) people security control 130 million yen; c) armed forces management 155 million yen; d) Improving education 150 million yen; e) improving science and technology 61 million yen .

The revenue from iron mining taxation and coral was about 9,995,000,000 yen. The gain from income tax was 6,580,000 yen. In the meantime, the national saving was increased and the people were pleased to support the government. This made the tax was easily collected and the bonds were quickly sold. The diversification of 
new taxations added the income to 1,140,000,000 yen yearly (Sinar Baroe, Januari 2064).

The Japanese expenditure was well managed where pound were easily collected, New bonds were sold to the public at the rate above 3,000 million yen. Since the war of Great East Asia was won by Japan, its economic condition became powerful. The economic relation of Japan in Asia indicated by the cooperation of Mantjoekoeo and Tiongkok in improving the economy. Poen Thai and Indo-China empowered Japanese labor. On the other hand, Japan gave aids its allies to improve their economy. Last year Japan invested 100 million yen in Mantjoekoeo and Tiongkok.

To enhance the wealth of Japan, the Japanese government made the new strategy for developing economy by making an agreement with its allies in Europe. Such agreements were: Developing New Economy, Highly appreciation for His excellence Gunseikan. To empower the economy in Java, Keizal Singikai (Economic Investigation Board) held the meeting to make the economic program for colonized areas on June 12, 1943, in Tyuucu Hookookaikan Djakarta.

The speech of His Excellency Gunseikan emphasized that the Dutch colonialization policy for centuries didn't make economic prosperity for Indonesian people. In order to improve the economic condition for the ever last prosperity of Indonesian people, there should be designed the basic development to bring Indonesian independence eventually.

The Japanese army designed a new economic structure based on the concept and idea of Netherland Indies economic goals by the establishment of the committee on the preparation for new economic people structure called Zyuumin Keisai Sintaisai Zumbi Inkai. This committee was also given charge to investigate the preparation of independence and designed the fundamental economic development as the basis for state establishment. During the war, there were three sectors in economy done consist of the increasing production rationally, collecting goods for government to fulfill war logistics; and distributing goods evenly to people.

In connection with the enemy landed in Tarakan and Balikpapan, and his further target was Sulawesi, the civilian navy of Japan strengthened the economy in the islands in order to protect Sulawesi from enemy attack. This protection could be done since the Japanese military during three years of his control had made the commodities overwhelming and military equipment, as well as the defense, were powerful.

Only in two-week of occupation, when the government set the price of the rice, $30 \%$ of them were given to government and day by day increased. In addition, the cooperation with Indonesian people, corn plantation, fishery, and seabird catching, freshwater fishery all were done successfully.

In Sulawesi, the weaving machine had been being prepared in order to be selfsufficient in clothing. This program was directed in South Sulawesi to continue the battle for self-determination to have independence. To support the South Sulawesi economy, some rules for popular crediting had been issued on July 2, 1943 as 
follows; a) people Bank established in major cities in South Sulawesi; b) each local bank owned capital at the amount of f100.000 or above and if this capital is lower than this amount, the local government will suffice; c) the local people banks are obliged to give loan to the people and pay them by installment based on the time set up, provide capital for credit institutions run by people and handle deposit as well establishing other banks; d) people Banks may not use their extra money unless they purchase shares determined by the government; e) people Banks will cooperate with rural banks which will be established at various sites (Sinar Baroe, Jumat 27 November 2062).

These rules were not yet understood by many merchants in the era of Japanese occupation. They said the rules were not published and communicated. Although there was a barn to raise the price, many merchants raised their goods price or they collected as many goods as possible and sold them when they had the expensive price. Anyhow, some merchants were arrested because of they against the rules. When they were caught before leaving Jakarta, they were not accused of collect trading goods proportionally and make price control in disorder (Soeara Asia, 7 Djoeni 2604). Purchasing goods irrationally depended on whether such goods traded legally or not. A merchant was said to against the rules when they bought the thing in the black market with illegal price.

\section{Japanese Policy in Foodstuff Plantation}

During the Japanese occupation, the cultivation of agricultural land in rural areas was agreed by the majority people to maximize rice production. During the Japanese occupation, the slogan "multiple folds of production" was implemented everywhere. This concept was communicated by the government at the meetings with community and published in various media.

With fertile land and huge manpower, South Sulawesi had a good condition for planting rice and by the end of Dutch period, south Sulawesi produced about 4 million tons a year. There were 3, 4 million acres of rice fields in 1940 or equivalent to $42,7 \%$ of the whole land in Sulawesi. However, since lack of technology, fertilizer, and fund to develop irrigation facilities, the plantation was done traditionally and brought about lower production. The average of harvest per acre in 1938-1939 was 1500, 3 kilograms of pounded rice or about $40 \%$ of Japanese production.at the same year. The variety of rice production in South Sulawesi depended upon local conditions.

There were three main rice producers in South Sulawesi such as Pare-pare, Bone, and Bonthain. Whereas the areas where lower rice productions were Mandar and Luwu. There was also production variety per capita where Pare-pare was the highest (345 kg) and the lowest was Bone (46 kg) (Sinar Baroe, 20 July 2065).

Although an increase of foodstuff production became a crucial program by the military government in the early of its occupation, this program needed a clear implementation just after November 1943 when the government made constitution called Kinhoji Sibokuoya Taisaku (Urgently Actions on Foodstuff Materials). With this program the government rules on increasing production were focused on a) 
introducing new rice variety; b) innovation of plantation technology; c) enhancing agricultural infrastructure; d) rice field expansion; e) propaganda and training for farmers. As the consequence of intensification program, there was no more land for cultivating particularly in Java. On the other hand, Japan had a high technology and experts which they wanted to transfer to Javanese farmers through those aspects mentioned above.

\section{The Policy on People Salt Industry}

Salt was considered important for it could not be replaced by other materials. Salt is our daily need besides rice. Salt is people property and so is rice to sustain their lives. This property may not be seized by the government but it should be maintained for maximum supply (Sinar Baroe, Jum'at 3 Juni 1942). How was the stock of the salt?

In the colonial government era, the stock of salt was arranged to fulfill the supply for five years. However, it had never been effective. The salt was produced by the government for one year between 100 and 300 thousand tons while the consumption was 300 thousand tons. Just in the years before the Second World war, the salt production got a little increase even the Japan adopted forced work (Romusha). The decrease of salt production in Madura was a clear indication when at the end of Japanese occupation, the principal of salt industry executed suicide because he was afraid and ashamed to welcome the Saiko Sikikan visit. As the anticlimax of salt famine was the cancelation of salt monopoly in April 1945.

By the early years of Indonesian republic government (1945, 1946 and 1947), the salt production in Madura even decreased lower to around $10 \%$ of the consumption. The decrease of this production was caused by lacking manpower in (Madura Ministry of Economic Affairs 1947). The salt industry that had employed 20,000 manpower, employed only 5.000 manpower. In addition to this salt famine, the transportation of salt in the land as well as in sea was also difficult. Meanwhile, the Japanese colonial government also canceled salt monopoly. The only way to overcome salt famine was to instruct all people who lived at the seashore to make salt. This policy was supported by the establishment of extension office of people salt.

The opportunities were well received by the people along the seashore at Jeneponto and Mandar. In making salt, the sea water was dried in the small pond and this resulted in form of white crystal with contained at least $80 \% \mathrm{NaCl}$. Salt industries employed thousand hundreds of people living along the seashore. Most of them had their own ponds, hired or were given by the government. For example, Jeneponto produced around 50 thousand tons in 2013.

It is obvious that salt industry which was done by people could guarantee an adequate stock to overcome salt famine. The government of Indonesia Republic who took over sovereignty from the Dutch still practiced salt monopoly. On the other hand, salt industry in Yogyakarta and Rembang were carried out although it collided with monopoly and this made the situation unfair. 
It does not matter whether the salt monopoly as colonial inheritance, was directed to finance the state. Anyhow, it is worthy to study further who will get benefit nowadays: the state or the people. Whether or not the salt monopoly be maintained?

\section{Cotton Plant Plantation}

In Dutch occupation era, the cotton productions were still low. In 1937, the plantation land was only about 4000 acres with raw cotton productions were around 6500 tons. Meanwhile, the consumption in Netherlands Indies were around 91000 tons. This means that there was only around 7 percent supplied by domestic production and the rest were imported. Cotton wool which was imported for the whole Netherlands Indies in 1939 was 13, 772 tons and cotton materials were 62,089 tons (Indische Verslag 1940: 344). By the time the Japanese occupied Netherlands Indies, cotton production was considered important. It was the reason why the plantation of cotton plants was urgently done and even importing cotton was quickly realized. Japanese government brought 3 million meters of white cloth and 5 million meters of gauze from Tokyo in October 1942 until March 1943 (US Department of Commerce 1963). However, there was no data whether or not such amounts were fulfilled. It was impossible to satisfy that lots since the shipment were very difficult because of the war in Great East Asia.

The Japanese military government announced a five-year plan to intensify cotton production in 1942 with a target of 350,000 kg and an area of 2500 acres. In 1943 , the target raised to $7,000,000 \mathrm{~kg}$ and an area of 30.000 acres. In 1944, the productions were $130.00000 \mathrm{~kg}$ with an area of 50.000 acres. In 1947 the productions reached $50.000 .000 \mathrm{~kg}$ with a planting area 180.000 acres (Sinar Baroe, 7 Juli 2063; Ministry of Economic Affairs 1947).

The five-year plan for planting cotton in Java and Sulawesi was carried out by collecting equipment, technicians, establishing a board named Mengka Saibai Kyokai. In December 1942 land had been prepared to be cultivated by various firms under the cooperation with some of the appointed local governments.

As the consequence of this program, the local government felt very difficult to get seeds and as the result, most of the seeds were imported from abroad particularly from Japan. Fortunately, under the aids of the Japanese navy, some thousands of "Express" seeds variety were brought to us from Sulawesi. In May 1943, thousands of seeds had been planted in thousands across in Sulawesi and Java.

A threat to the cotton plantation in hot land in South area came from the cotton pest. To eliminate such pest, the technicians of the firms controlled the coming pests and killed them to reduce their attack. There was also sort of bumblebee pests in Bantaeng and Bulukumba with the local name Kilanka. In Malang existed other pests but they all could be killed with pesticide materials and by catching them. The pests attack happened when cotton plants started to bloom and at this time the pest should be destroyed. Generally, plant maintenance was said to be successful although it was not totally perfect. In addition to this pest, there were also weeds which the Japanese 
called them Hamasuge. These weeds grew rapidly so they needed a lot of manpower to pull them up.

Another factor which affected the cotton production was the weather. Fortunately, the weather condition in 1943 was much rain compared to the previous years. That was why the cotton plants that were planted in December had an extralong branch. In contrary to Java and Sulawesi island, the Philippines and Taiwan where there were often attacked by storm, Java and Sulawesi islands almost had no storm during the cotton plantation. This situation resulted in appreciation to cotton plantation firms in Java and Sulawesi eventually (Sinar Baroe, 2063).

Because of price determination, oc cotton produced in Java influenced the cotton plantation firms eventually, and this condition had been well considered by the government. Nowadays cotton price which had been set up by the government as the following a) class 1 . Rp 18 per $100 \mathrm{~kg}$; b) class 2. Rp 16 per $100 \mathrm{~kg}$; c) original variety in Makassar Rp 13 per $100 \mathrm{~kg}$. The prices based on the purchasing places according to each area, the price determination involved the costs of plantation so that the farmer eventually could establish their own firms (Sinar Baroe, 2063).

\section{Castor-oil Plant Plantation}

In the meeting of Nomuka representative, he said that of all war equipment, an airplane is said to be vital to win the war in Great East Asia. Castor-oil contributed as a source of energy to win the war. Castor-oil seeds produce oil which can be used as fuel for the airplane. The atmosphere of Sulawesi is good to plant castor-oil seeds. How far the contribution of castor-oil seeds to war arms could be indicated that every 280 castor-oil trees were able to fly a bomber airplane 20 hours long or equivalent to 14 trees per hour. For training airplane, it needed only 4 trees for an hour flight.

In addition, castor-oil with Java variety could deliver more yields until 20,000 fruits per one tree (Post 1991). A thousand of good quality castor-oil fruit weighted 50 gr whereas the common quality weighted only 35 grams. An average tree could yield 400 grams and when this amount was distilled, it could result from 180 grams of oil.

Other plants to be obliged to farmers were castor for lubricating oil. Before the war, South Sulawesi had a limited production especially in Gowa, Bontain, Bulukumba, and Bone, this production was only around 10.000 tons. At that time, there was $30 \%$ of castor oil exported by South Sulawesi to Japan. This oil was particularly used as the lubricating material for airplane machine and since the war, the need for this oil by Japanese army increased rapidly. Japanese military government in Makassar tried to increase castor oil production. He set up the target from the amount of 40,000 tons in 1943 to rise up to 60.000 tons in 1944 . To satisfy this target, a great campaign had been started since 1942 and to be continued during occupation time (Sinar Baroe, 2063). 


\section{Weaving Cotton Cloth in South Sulawesi}

In addition to farms, spinning and weaving cotton were also encouraged in rural areas. Training and courses for spinning were carried out by every level of government. For example, in Bone and Sinjai regencies, there were two representatives of Fujinkai from every district sent to regency capital city and trained for three months in 1944. This training was sponsored by Hokokai and Fujinkai at regency branch offices led by regent's wife. The trainees stayed at the boarding house near a regent office. They learned how to extract the raw cotton fibers from its seeds (kernels) and span them into cotton fibers. After training, they went back home and executed the same training at the district level. The trainees at this level came from every village. The tools used in training to extract and spin the cotton were provided by the government. The costs for training, food, and accommodation of the trainees were provided by Hokokai.

In Malino, Gowa Regency, some schools of cotton spinning existed permanently. With these courses, the technique of spinning cotton had been mastered by rural people. As the result, many householders ran this business. With the cotton fibers they produced, the householders started to weave and activated the traditional weaving tools (Chaniago 1985). Before the war (1941) there were many hands weaving tools for industry in the hinterlands area of Buginese. With the Japanese support, weaving as home industries developed in many areas in South Sulawesi. They made their own tools imitating the tools provided by the government. In many cases, the scale production of weaving was small and just for satisfying the need of the family. They, however, probably sold one or two pieces of their productions if there were a surplus or they needed cash for expenditures.

According to $\mathrm{H}$. Ambo in Sinjai, one could sell a piece of sarong weaved by hand in the black market with the price of $400 \mathrm{~kg}$ rice equivalent. One piece of sarong took four days to weave. Because of its lacking, the cloth could be used as media of exchanges or barter. It was estimated that a piece of sarong needed 300 grams of raw cotton while this amount was harvested in two square meters of land.

Spinning and weaving as the home industry in Maros were carried out in every area. With this condition, the shortage of cloth could be overcome for a certain level after 1944. The skill of farming, spinning and weaving in rural people then revitalized under Soekarno regime with the slogan Berdiri di Atas Kaki Sendiri (Berdikari: self-sufficient), and manual weaving machine made in Japanese occupation were reused and given name as woven non-machine or Alat Tenon Bukan Mesin (Sinar Baroe, Selasa 7 Juli 2043)

Regardless this home industry, raw cotton that was sold to Japan lastly were given to spinning manufactures controlled by the government. The total productions of cotton fibers and cloth at the end of occupation were cotton fibers 171.600 pounds/month, wide cloth 270.000 /month, and narrow cloth 2.830 pieces/month.

Other textile materials which were encouraged by Japanese authority included hard fibers such as hemp, jute, rosella, and mulberry (Berita Ekonomi, 1954: 17-19). Hemp and jute were put in priority since these materials had fibers relatively soft 
and could be made clothing material as well bags for agricultural products. All farmers who have interviewed complaint about lacking cloth and gunny sack for shorts in Japanese occupation.

In the Dutch period, eight millions of gunny sacks were produced a year although this amount satisfied only 35\% of the demands and the rest of it should be imported from India. Since the import was stagnant, Japan had to satisfy their needs and in June 1942 through the intensification program called Nanpo Ko-Niki Asarui Zosan Keikaku Yoko in Ko area, Southeast Asia. This program was designed by Planning Bureau (Kikakuin) of Japanese Government. Based on this program, there were 81 productions targeted for Rosela and gunny sack between 1942 and 1947.

With good natural condition and energetic people, the cotton plantation in the whole Sulawesi had started and given good prospect. It was hoped that in the next five years the production became multifold. According to the report written by an expert that the weather and land, either in the whole region of Sulawesi were more suitable for cotton plantation.

\section{Conclusion}

This study is about economic policy and its implementation in the area where Japanese navy governed especially in South Sulawesi. The existence of Japanese government in South Sulawesi at Second World War seemed to have two major interests. Firstly, Makassar was made as a center maritime fleet of the Japanese navy, and secondly, South Sulawesi was driven to empowering the war logistics. These two aspects gave impacts on the type of strategies in political and economic policies implemented in South Sulawesi. This was quite different in paddy-field, where people were directed to be Romusha and labors in various sectors of mining and plantations. Whereas in South Sulawesi, Japanese was more cooperative with local kings, related to economic development. Not only was the different type and policy characteristics based on the individual area but also the characteristics of the population became the main consideration for policy implementation. In addition, there was also a polarization between Japanese army and navy in Java. Such polarization was interesting to study in order to get a deeper understanding about the history of Japanese occupation in Indonesia, especially in South Sulawesi during the war period i.e., decolonization period and the replacement of Dutch regime to Japanese occupation. The way of Local kings fought against the Dutch seemed has affected the local king's attitude to be loyal to the Japanese government. In fact, this research is supposed to correct various researches done by historians and other scientists who were concerned to the dynamics of Japanese local history in Indonesia and who were tended to equalize Java and outside Java.

\section{References}

Berita Ekonomi, 1954.

Chaniago, J. R. Editor. (1985). Di Bawah Pendudukan Jepang. Jakarta: Arsip Nasional Republik Indonesia. 
Indische Verslag, 1943.

Kurasawa, A. (1993). Mobilisasi dan Kontrol, Studi tentang Perubahan Sosial di Pedesaan Jawa 1942-1945. Jakarta: Gramedia.

Mailrapport Nomer 317/23 MvO Serie 2e Rol Nomer 23 Koleksi ANRI Jakarta.

Murtono, S. (1968). State and Statecraft in Old Java: A Study of the Later Mataram Period, Sixtenth to Nineteenth Century. Ithaca: Cornell Modern Indonesian Project.

Paeni M. (1985). Sejarah Sosial Daerah Sulawesi Selatan: Mobilitas Sosial Kota Makassar. Jakarta: Departemen Pendidikan dan Kebudayaan Direktorat Sejarah dan Nilai Tradisional Proyek Inventarisasi dan Dokumentasi Sejarah Nasional.

Portelli, A. (1991). The Death of Luigi Trastulli and Other Stories: Form and Meaning in Oral History. Albany: State university of New York Press.

Post, Peter (1991). Japanese Bedrijvigheid in Indonesia, 1868-1942. Structurele Elementen van Japan's Economische Expansie in Zuidoost Azie. Academisch Proef schrift Vrije Universiteit Amsterdam.

Sinar Baroe, 20 July 2065.

Sinar Baroe, 25 Juli 2065.

Sinar Baroe, 25 Juli 2065.

Sinar Baroe, Jumat 27 November 2062.

Sinar Baroe, June 2604

Soeara Asia, 18 Mei 2064.

Soeara Asia, Januari 2064.

Sutter, John O. (1959). "The Indonesian Economy During the Revolution." "Indonesianisasi Politics a Changing Economy, 1940-1950. Vol. 2." Ithaca: Departement of Far Eastrn Studies Cornell University.

US Department of Commerce. (1963). "Japanese Military Administration in Indonesia." Technical Services. 